\title{
Detection of Aflatoxins, Mutagens and Carcinogens in Black, White and Green Peppers (Piper Nigrum L.)
}

\author{
Jesús Ismael Garduño-García ${ }^{1}$, Magda Carvajal-Moreno ${ }^{1^{\star}}$, Francisco Rojo-Callejas ${ }^{2}$ and Silvia Ruiz-Velasco ${ }^{3}$ \\ ${ }^{1}$ Instituto de Biología, Universidad Nacional Autónoma de México, Ciudad Universitaria, Coyoacán, 04510 Ciudad de México, México \\ 2Departamento de Química Analítica, Facultad de Química, Universidad Nacional Autónoma de México, 04510 Ciudad de México, México \\ ${ }^{3}$ Departamento de Probabilidad y Estadística, Instituto de Investigaciones en Matemáticas Aplicadas y en Sistemas, UNAM, 04510 Ciudad de México
}

\begin{abstract}
Aflatoxins, bis-dihydro-furancoumarins, are secondary metabolites that are produced by molds of Aspergillus $\mathrm{sp}$. with adverse effects in humans and animals. The International Agency for Research on Cancer classifies aflatoxins in Group 1 of proven human carcinogens. Thus, aflatoxins in foods are highly regulated throughout the world. The purpose of this research was to identify and quantify aflatoxins in 54 pepper samples (19 black, 19 white and 16 green peppers) from markets in Egypt, India, Turkey and the 16 boroughs of Mexico City, as well as to validate the experimental method used. All samples were contaminated with at least one aflatoxin: $95 \%(51 / 54)$ were contaminated with aflatoxin $B_{1}\left(0.1\right.$ to $\left.218 \mu \mathrm{g} \mathrm{kg}^{-1}\right) ; 80 \%$ (43/54) with aflatoxin $\mathrm{B}_{2}\left(0.4\right.$ to $\left.382 \mu \mathrm{g} \mathrm{kg}^{-1}\right) ; 67 \%$ $(36 / 54)$ with aflatoxin $G_{1}\left(0.4\right.$ to $\left.612 \mu \mathrm{g} \mathrm{kg}^{-1}\right)$; and $93 \%(50 / 54)$ with aflatoxin $\mathrm{G}_{2}\left(1.37\right.$ to $\left.494 \mu \mathrm{g} \mathrm{kg}^{-1}\right)$. Only $9.26 \%$ of the samples $(5 / 54)$ were under the Mexican legislation limit, whereas all foreign samples surpassed the limits established for their respective countries.
\end{abstract}

Although the aflatoxin concentrations in peppers are high, their ingestion is minimal because peppers are used in only small quantities as a flavor-enhancing product. Therefore, the contribution of aflatoxins from a pepper to an organism is relatively low in comparison to other agricultural products, such as maize, pistachio, peanuts and dairy products. Green pepper was the most contaminated with aflatoxins, white pepper was the least contaminated and black pepper had an intermediate level of contamination. This study describes a detailed analysis of aflatoxin contamination in pepper in three different ripening stages: green, black and white. The lack of normativity in countries on this subject prevents the reduction of $\mathrm{AF}$ concentrations in the diet.

Keywords: Pepper; Carcinogens; Aflatoxins; Spice contamination

\section{Introduction}

Pepper (Piper nigrum L.) is the most important spice with economic value and is used as an ingredient in many dishes to give flavor to foods. Piper nigrum L. is also a tropical arbust that forms clusters or racemes in warm climates of 25 to $30^{\circ} \mathrm{C}$ and 60 to $93 \%$ humidity $[1,2]$. The different types of peppers are due to the different ripening stages of the grains. Green peppers are unripened grains that are dried or preserved in vinegar or citric acid. Black peppers are harvested halfway through the maturation period when they are green-yellowish, and their berries are submerged in boiling water for $10 \mathrm{~min}$. This treatment favors fermentation, which produces the black color and disinfects the surface. Black berries are sun-dried for 2 weeks to reach $12 \%$ humidity; this type of pepper has been the most commonly used since ancient times. White peppers are mature, peeled grains without a husk; they are harvested when they are red or orange in color, soaked in water for one week to peel them and are later dried until they have a white-brownish color. The flavor of white pepper is milder than that of black pepper [1].

Pepper is found in five continents, and its economic value is more than $1,000,000,000$ US dollars [3]. The countries that produce the most pepper are Vietnam (146,000 tons), Indonesia (65,000 tons), Brazil (44,610 tons) and China (31,963 tons) [4]. Mexico is not a sufficient producer of pepper (6,335 tons); therefore, it imports black pepper [2]. The main production states in Mexico are Veracruz (5,053.7 tons), Tabasco (900 tons), Chiapas (174 tons), Puebla (138.5 tons) and Oaxaca (2.8 tons) [2]. In 2009, Veracruz was the most productive state, contributing $53.5 \%$ of the sown surface, $80.6 \%$ of the volume production and $59.2 \%$ of the generated value [2] (Figure 1).

Between 2000 and 2008, world-wide pepper production increased by $31.8 \%(414,849$ tons) [2]. The world's pepper consumption is approximately 350,000 tons [5].

In spices, fungal growth occurs in warm and humid conditions [6]. Chemically, aflatoxins (AFs) are bis-dihydrofuran coumarins, fluorescent compounds with chemical structures and physicochemical properties that are well-described [7]. They are secondary toxic metabolites produced between 25 and $35^{\circ} \mathrm{C}$ by Aspergillus flavus, $A$. parasiticus, A. nomius and $A$. pseudotamarii and they can affect human health [6].

In A. flavus and A. parasiticus, growth occurs at a relative humidity ranging from 88 to $95 \%$, a $\mathrm{pH}$ between 3.5 and 5.5 and at a high water activity (wa). Other factors that are important for fungal growth and AF synthesis are the environmental gaseous composition and light. Some aerobic fungi grow well at a concentration of $20 \% \mathrm{CO}_{2}$; however, at $10 \%$ $\mathrm{CO}_{2}$, they cease AF production [8].

The main types of $A F s$ in pepper are aflatoxin $\mathrm{B}_{1}\left(\mathrm{AFB}_{1}\right)$, aflatoxin $B_{2}\left(A_{F B}\right)$, aflatoxin $G_{1}\left(A F G_{1}\right)$ and aflatoxin $G_{2}\left(A F G_{2}\right)$. AF toxicity in decreasing order is $\mathrm{AFB}_{1}>\mathrm{AFG}_{1}>\mathrm{AFB}_{2}>\mathrm{AFG}_{2}[9]$.

*Corresponding author: Magda Carvajal M, Instituto de Biología, Universidad Nacional Autónoma de México, Ciudad Universitaria, Coyoacán, 04510 Ciudad de México, México, Tel: 525556229138; 5525238197; Fax: +5255 55501760; E-mail: magdac@ib.unam.mx

Received April 21, 2017; Accepted May 15, 2017; Published May 22, 2017

Citation: Garduño-García JI, Carvajal-Moreno M, Rojo-Callejas F, Ruiz-Velasco S (2017) Detection of Aflatoxins, Mutagens and Carcinogens in Black, White and Green Peppers (Piper Nigrum L.). J Microb Biochem Technol 9:095-104. doi: 10.4172/1948-5948.1000350

Copyright: (C) 2017 Garduño-García Jl, et al. This is an open-access article distributed under the terms of the Creative Commons Attribution License, which permits unrestricted use, distribution, and reproduction in any medium, provided the original author and source are credited. 


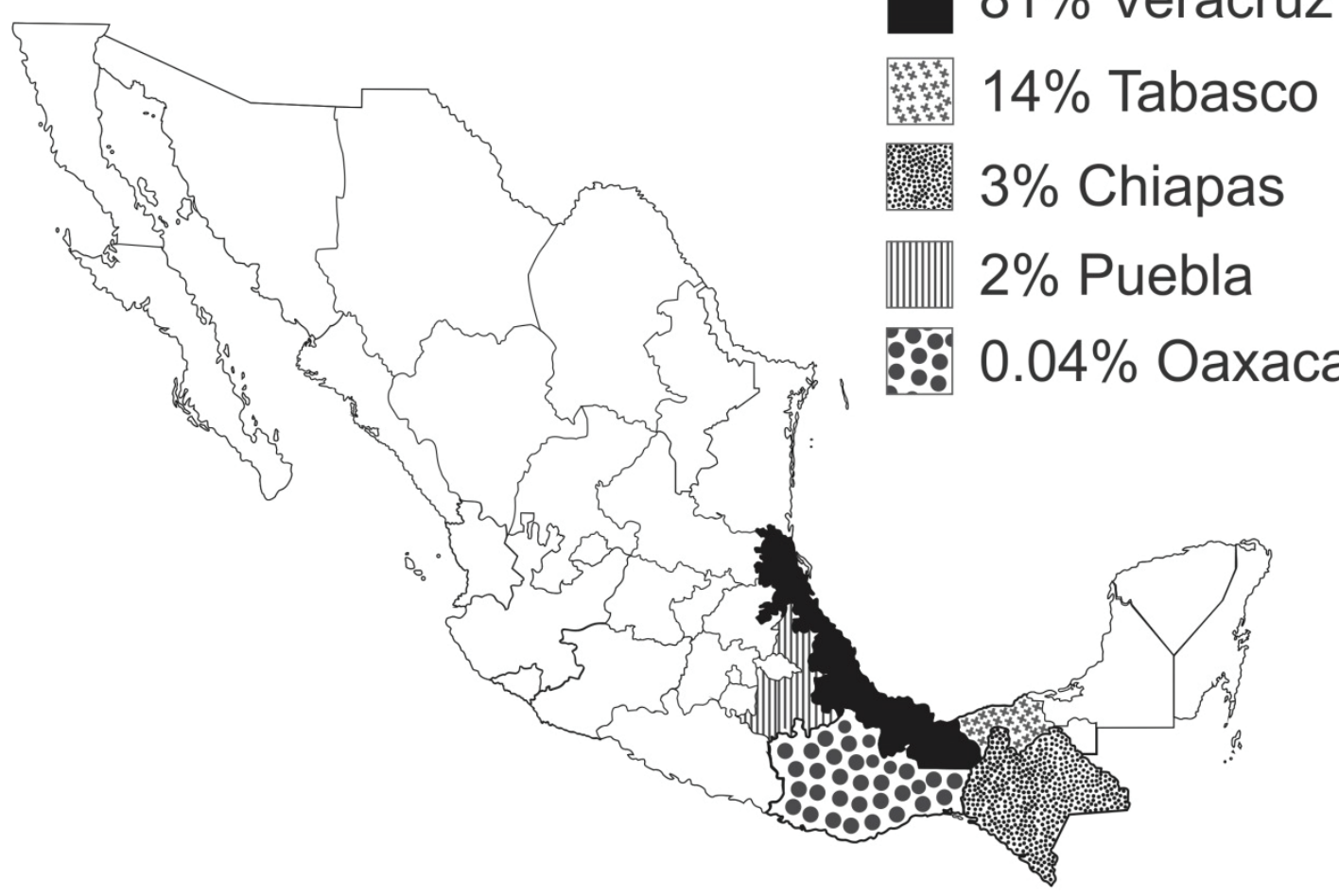

Figure 1: The five Mexican States that produce pepper are Veracruz, Tabasco, Chiapas, Puebla and Oaxaca [2].

The ingestion of foods contaminated with AFs predisposes humans and animals to disease and ultimately death [10]. The most common cause of chronic intoxication (for weeks, months and years) is the ingestion of small quantities of AFs in foods. AF consumption results in damaging effects, such as immunosuppression, hemorrhages, malformations, abortions, fetal diarrhea, vomiting, growth deficiency, certain types of cancer and death, depending on the time of consumption and the quantities ingested.

In general, the effects of AFs in humans are limited due to the number of cases [11]. Acute AF exposure has been associated with hepatitis B epidemics in China and Africa, with death rates ranging from 10 to $60 \%$ [12]. AF exposure is also associated with human hepatocellular cancer that worsens in the presence of hepatitis B virus [13]. There is also a synergetic effect between exposure to AFs and some diseases, such as malaria, Kwashiorkor, Reye's syndrome and AIDS in children [14]. One case from Senegal showed that the daily consumption of 5 to $20 \mu \mathrm{g} \mathrm{kg}^{-1}$ AFs in body weight caused abnormalities in the livers of children with Kwashiorkor within 10 months due to the ingestion of an AF-contaminated protein supplement that is used to treat this disease [15].

$\mathrm{AFs}$ are potent carcinogens and classified by the International Agency for the Research of Cancer as Group 1 therefore, AF levels in foods are regulated throughout the world [16]. In the European Union and Turkey, the maximum tolerance level for AFs in spices, such as pepper (Piper spp.), is $5 \mu \mathrm{g} \mathrm{kg}^{-1}$ for $\mathrm{AFB}_{1}$ and $10 \mu \mathrm{g} \mathrm{kg}^{-1}$ for total aflatoxins (AFt). CODEX Alimentarius has established maximum tolerance limits of $15 \mu \mathrm{g} \mathrm{kg}^{-1} \mathrm{AFt}$ for some processed nuts and $10 \mu \mathrm{g}$ $\mathrm{kg}^{-1}$ for foods that are ready for consumption based on JECFA [17]. In México, the legal accepted limit is up to $20 \mu \mathrm{g} \mathrm{kg}^{-1} \mathrm{AFt}$ for cereals, but there is no legislation for spices; therefore, peppers are not regulated.
The decreased susceptibility of animals to AFs ranges from poultry (ducks $<$ turkey $<$ chickens) to mammals (dogs $<$ pigs $<$ veal $<$ sheep $<$ cattle). AFs cause non-specific symptoms in animals, including a reduction in weight, a decrease in egg and milk production, and an increased susceptibility to infections, mutations and cancer in rats [18]. Thymus depression and a decrease in $\mathrm{T}$ cell function and cellular immunity are the observed effects of AFs in bovines, sheep and pigs [19-21].

Ruminants are more resistant to the effects of AFs because the microbiota can degrade AFs within the rumen $[22,23]$. It is likely that the sheep's rumen can detoxify AFs and make them resistant to up to $500 \mathrm{mg} \mathrm{kg}^{-1} \mathrm{AFs}$ [24]. Macaque monkeys have a $\mathrm{DL}_{50}$ value of $7.8 \mathrm{mg}$ $\mathrm{kg}^{-1}$ for females and $2.2 \mathrm{mg} \mathrm{kg}^{-1}$ for males; the $\mathrm{DL}_{50}$ in small ducks $(0.4$ $\left.\mathrm{mg} \mathrm{kg}^{-1}\right)$, rats $\left(1.0 \mathrm{mg} \mathrm{kg}^{-1}\right)$, sheep $\left(500 \mathrm{mg} \mathrm{kg}^{-1}\right)$, and pigs varies from 0.3 to $0.6 \mathrm{mg} \mathrm{kg}^{-1} \mathrm{AFB}_{1}$ [15,25]. Oral ingestion of $4 \mathrm{mg} \mathrm{kg}^{-1} \mathrm{AFs}$ kills bovines within $15 \mathrm{~h}$ due to acute liver failure [24]. $\mathrm{AFB}_{1}$ is the most toxic and well-studied AF with respect to its carcinogenic and cytotoxic effects. A single dose of $5 \mathrm{mg} \mathrm{kg}^{-1} \mathrm{AFB}_{1}$ in rat feed for 6 weeks inhibits DNA and RNA synthesis [26].

Studies on the ingestion of pure AFs in suicide attempts have demonstrated that unusually high dosages $(5.5 \mathrm{mg}$ for two days and 53 mg for 2 weeks) cause transitory skin eruptions, nausea and headaches up to 6 months later and are not as effective as long-term doses. A woman who attempted suicide completely recovered without liver lesions when examined 14 years later [27]. Therefore, it was concluded that subacute prolonged dosages are necessary to induce toxic lethal effects (i.e., with pepper, the ingestion of small dosages for a long time) [27]. The purpose of this study was to determine the contribution of pepper to AF contamination in food. 


\section{Methods and Materials}

\section{Sampling}

The estimated current population of Mexico is approximately $130,139,368$ inhabitants. Mexico City is the capital city of Mexico, with a population of 21.3 million people [28]. Mexico City contributes $20 \%$ of Mexico's entire population, making it the most populous metropolitan area in the Western Hemisphere and one of the most densely populated cities in the world [29]. Mexico City is divided into 16 boroughs and receives food from the entire country. Therefore, it is a reliable sampling site to gain an understanding of pepper consumption in Mexico. $50 \mathrm{~g}$ samples of the three types of peppers (green, black and white) were obtained from the three most important markets from each of the 16 boroughs of Mexico City (Figure 2).

Green peppers from foreign countries were not analyzed. Pepper grinding (Moulinex ${ }^{\circledR}$ Model AR6838C6, Mexico City, Mexico) was performed with the entire grain of each pepper. In the case of the boroughs of Mexico City, $17 \mathrm{~g}$ of pepper from each of the three markets per borough were mixed to obtain a compound sample of $51 \mathrm{~g}$. For foreign peppers, a $51 \mathrm{~g}$ weight was applied directly to each sample.

\section{Method validation}

Validation is the process of establishing, through laboratory studies, a satisfactory chemical method that is suitable to analyze samples [30]. Method validation was based on Rule 401/2006 of the European Commission and on the criteria for the physicochemical method of the Ministry of Health of Mexico according to the following parameters $[30,31]:$

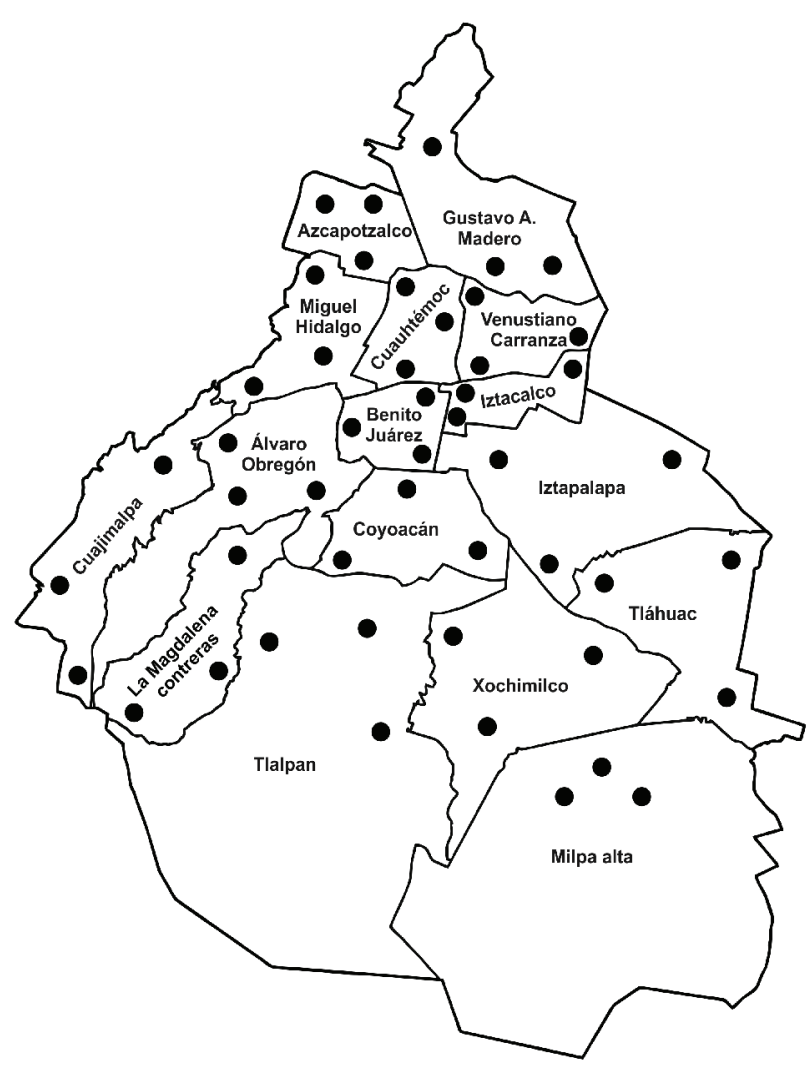

Figure 2: Mexico City divided in 16 boroughs where the three most important markets were sampled for green, white and black pepper. a. Selectivity: Selectivity is the ability of a chemical process to differentiate analytes (in this case the four AFs) from other compounds of a complex matrix. We used three matrices of pepper (black, white and green) in an independent manner, with a mixture of the four AF standards (100 ng each). As a control, we used a mixture of the four AF (100 ng) standards alone. The chromatograms were compared to determine whether the AF peaks of the three matrices overlapped with the control. The retention times were consistent.

b. Lineality: Lineality is the capacity of an analytical method to obtain calibration curves that are directly proportional to the concentration of the analyte. A stock solution of $1 \mu \mathrm{g} \mathrm{mL}{ }^{-1}(=1000$ ng) of each AF (Sigma-Aldrich, St. Louis MO, USA) was prepared following the AOAC methodology [32]. Standards were diluted independently with benzene/acetonitrile $(98: 2 \mathrm{v} / \mathrm{v})$ and homogenized, and their absorbance was measured on a UV-visible spectrophotometer (Genesys 10 UV, Thermo Electron Corporation, Madison, WI, USA) and adjusted to zero using pure HPLC methanol as a blank control [32]. The following equation was applied to determine the amount of $\mathrm{AF}$ and methanol needed to obtain $1 \mathrm{~mL}$ of an AF concentration of $1 \mu \mathrm{g} \mathrm{mL}{ }^{-1}$ (=1000 ng):

\section{$\underline{\text { Absorbance } \times \mathrm{AF} \text { molecular weight }}=\mathrm{x}$}

\section{Extinction coefficient}

$1 / \mathrm{x}=\mu \mathrm{L}$ of $\mathrm{AF}$ in unknown solution

$1000 \mu \mathrm{L} \mathrm{MeOH}-\mu \mathrm{L}$ AF of problem solution $=\mu \mathrm{L}$ of $\mathrm{MeOH}$ to add

The molecular weight (MW) and extinction coefficient (EC) at absorbances of 360 to $362 \mathrm{~nm}$ were: $\mathrm{AFB}_{1}$ (MW 312; EC 21,800), $\mathrm{AFB}_{2}$ (MW 314; EC 24,000), $\mathrm{AFG}_{1}$ (MW 328; EC 17,700) and $\mathrm{AFG}_{2}(\mathrm{MW}$ 330; EC 17,700).

The 16 AF concentrations $(0.01,0.05,0.1,0.5,1,2,4,8,16,32$, $64,128,200,600,800$ and $1000 \mathrm{ng} \mathrm{mL}^{-1}$ ) were made using the stock solution $(1000 \mathrm{ng})$ from each of the four AFs. Calibration curves were generated by Microsoft Excel.

\section{Limit of detection (LOD) and limit of quantification (LOQ)}

The LOD of the equipment was established in relation to the noise in the chromatogram. The LOD equals the concentration of the AF that yields a signal that is three times greater than that of the noise. The LOQ equals the concentration of the AF that is 10 times greater than that of the noise [33].

\section{Recovery percentages}

The results of this experiment complied with the acceptance criteria of the European Community (EC) and the criteria of the physicochemical methods of the Ministry of Health of Mexico (SSA) $[30,31]$.

The recovery percentage is a measure of the accuracy of a method and represents the proximity between the theoretical and experimental values. The recovery percentage in this study is the amount of recovered $\mathrm{AF}$ from a spiked sample. To determine the recovery percentage, $1 \mathrm{~g}$ aliquots of dried, ground pepper were individually spiked with three different concentrations $\left(5,20\right.$ and $\left.40 \mu \mathrm{g} \mathrm{kg}^{-1}\right)$ of each $\mathrm{AF}\left(\mathrm{AFB}_{1}\right.$, $\mathrm{AFB}_{2}, \mathrm{AFG}_{1}$ and $\mathrm{AFG}_{2}$ ) and each spiked aliquot was subjected to the complete analytical method. The arithmetic average, standard deviation, percentage of variation coefficient and confidence interval were calculated. One aliquot without $\mathrm{AF}$ was used as a control, which represented the basal level of contamination. The samples were 
individually processed according to the R-Biopharm extraction method [34]. AFs were purified and concentrated using an immunoaffinity column, derivatized, and quantified by HPLC to obtain the percentage of recovery of each AF. When the derivatized mixture cooled to room temperature, $20 \mu \mathrm{L}$ of each sample were injected for HPLC analysis. Each sample was run in triplicate. For more accurate results, the concentrations of AFs were adjusted once the recovery percentages were obtained.

\section{Chemical extraction}

Each representative sample of $51 \mathrm{~g}$ of pepper was blended (Black \& Decker "Crush Master") with $100 \mathrm{~mL}$ of a solution of acetonitrile $(\mathrm{ACN})$ HPLC (JT Baker, Xalostoc, México)/distilled water $(60: 40 \mathrm{v} / \mathrm{v})$ and $2 \mathrm{~g}$ of sodium chloride (JT Baker, Xalostoc, México) for $1 \mathrm{~min}$ to clarify the extract. The extracts were filtered and $2 \mathrm{~mL}$ (equivalent to $1 \mathrm{~g}$ ) of the extracts were dissolved in $48 \mathrm{~mL}$ of phosphate-buffered saline (PBS, pH 7.4) and vortexed. The mixture was then applied to an immunoaffinity column (Easi-Extract Aflatoxin, Biopharm Rhône Ltd., Glasgow, Scotland) that was previously balanced with $20 \mathrm{~mL}$ of PBS and washed with $20 \mathrm{~mL}$ of distilled water. Air was passed through the column and AFs were eluted with $1.5 \mathrm{~mL}$ of methanol (MeOH) HPLC (J.T. Baker, Xalostoc, México). Distilled water $(1.5 \mathrm{~mL})$ was refluxed to separate the antibodies in the agarose gel and to recover pure AFs in the eluate. The eluates were collected in labeled amber vials, dried at $40^{\circ} \mathrm{C}$ in an oven (Novatech BTC-9100) and stored in a refrigerator.

\section{Derivatization}

The AFs have different fluorescent properties; therefore, a derivatization reaction that consists of acid hydrolysis of the double bonds of the dihydrofurane ring was applied to produce the $A F B_{2 a}$ and $\mathrm{G}_{2 \mathrm{a}}$ types, the fluorescence of which is comparable to that of $\mathrm{AFB}_{2}$ and $\mathrm{AFG}_{2}$ in an aqueous solution [35].

The AF standards were dried and resuspended in $200 \mu \mathrm{L}$ of ACN. To enhance fluorescence, $800 \mu \mathrm{L}$ of a derivatizing solution was added. The derivatizing solution consisted of $5 \mathrm{~mL}$ of trifluoroacetic acid (Sigma-Aldrich, St. Louis MO, USA), $2.5 \mathrm{~mL}$ of glacial acetic acid (Merck, Naucalpan, Edo. Mex., México) and $17.5 \mathrm{~mL}$ of deionized water. The mixture was vortexed (Vortex G-560, Bohemia, NY, USA) for $30 \mathrm{~s}$. The vials were placed in a water bath (Aparatos de Laboratorio BG, Mod. BM 40T) at $60^{\circ} \mathrm{C}$ for $10 \mathrm{~min}[35,36]$. The vials were cooled to room temperature and $20 \mu \mathrm{L}$ were injected into the HPLC for AF quantification.

\section{AF quantification by liquid chromatography}

AF standards and samples were analyzed on an HPLC Agilent Series 1200 with an isocratic pump (G1310A Serie DE62957044), fluorescence detector (G1321A Series DE60456380) and autosampler (G1329A Series DE64761666) using a chromatographic column (Agilent Eclipse XDS-C18, $4.6 \times 250 \mathrm{~mm}$ ) with a particle size of $5 \mu \mathrm{m}$. The program used for HPLC was ChemStation 32. The analysis conditions were: mobile phase $\mathrm{H}_{2} \mathrm{O} / \mathrm{ACN} / \mathrm{MeOH}(65: 15: 20 \mathrm{v} / \mathrm{v} / \mathrm{v})$; injection volume of $20 \mu \mathrm{L}$; flux of $1 \mu \mathrm{L} \mathrm{min}{ }^{-1}$; analysis time of $25 \mathrm{~min}$; and excitation wavelength of $362 \mathrm{~nm}$. Two different emission wavelengths were used: $425 \mathrm{~nm}$ for $\mathrm{AFB}_{1}$ and $\mathrm{AFB}_{2}$ and $450 \mathrm{~nm}$ for $\mathrm{AFG}_{1}$ and $\mathrm{AFG}_{2}$.

\section{Statistical analysis}

The sample-adjusted results of the three peppers were compared by borough for Mexico City, as well as for Egypt, India and Turkey. To identify potential differences between the place of origin of the sample and the three stages of maturation of the pepper, a non-parametric
Kruskal-Wallis test and a Wilcoxon signed-rank test were performed to determine the differences between each group.

AF contamination in spices is frequent and at high amounts that surpass that values set by international legislation. Therefore, the purpose of this research was to identify and quantify $A F s\left(A_{1} B_{1}\right.$, $\mathrm{AFB}_{2}, \mathrm{AFG}_{1}$ and $\mathrm{AFG}_{2}$ ) in green, black and white peppers consumed in Mexico, Egypt, Turkey and India and to determine whether AF contamination contributes to food carcinogens in the human diet.

\section{Results and Discussion}

\section{Method validation}

The validation parameters for each aflatoxin obtained in the experiments of linearity, selectivity and recovery percentage is presented.

\section{Selectivity}

After analyzing the three types of peppers spiked with $100 \mathrm{ng} \mathrm{g}^{-1}$ of each of the four AFs and the blank or the control, the chromatograms obtained showed signals for the four AFs. The first chromatographic peak ( 6 min) corresponded to $\mathrm{AFG}_{1}$, the second to $\mathrm{AFB}_{1}(\sim 8.5 \mathrm{~min})$, the third to $\mathrm{AFG}_{2}(\sim 12.5 \mathrm{~min})$ and the fourth to $\mathrm{AFB}_{2}(\sim 19 \mathrm{~min})$. The order of the four analytes did not change due to the effect of the different matrices (i.e., there was no overlap among the signals and there was no interference with any compound of the matrix) (Figure 3).

\section{Lineality}

The calibration curves were constructed with the different concentrations of the four AFs. The aflatoxin concentrations (ng $\mathrm{mL}^{-1}$ ) for the calibration curves were as follows: $\mathrm{AFB}_{1}(0.1,0.5,1,2,4,8,16$, 32,64 and 128) with $\mathrm{R}^{2}=0.9973, \mathrm{AFB}_{2}(0.01,0.05,1,5,10,20,40,70$, 100 and 200) with $\mathrm{R}^{2}=0.9908, \mathrm{AFG}_{1}(0.01,0.05,0.1,0.5,1,4,16,100$ and 128) with $\mathrm{R}^{2}=0.9969$ and $\mathrm{AFG}_{2}(0.5,1,2,4,8,16,32,64,100,200$, 600,800 and 1000 ) with $\mathrm{R}^{2}=0.9988$. The $\mathrm{R}^{2}$ obtained in the calibration curves showed precision and confiability (Table 1).

\section{Limit of detection (LOD) and limit of quantification (LOQ)}

The LOD and LOQ were in $\mathrm{ng} \mathrm{mL}^{-1}: \mathrm{AFB}_{1}(\mathrm{LOD}=0.1 ; \mathrm{LOQ}=0.5)$, $\mathrm{AFB}_{2}(\mathrm{LOD}=0.01 ; \mathrm{LOQ}=0.05), \mathrm{AFG}_{1}(\mathrm{LOD}=0.01 ; \mathrm{LOQ}=0.05)$ and $\mathrm{AFG}_{2}(\mathrm{LOD}=0.5 ; \mathrm{LOQ}=2.5)$ (Table 1$)$.

\section{Recovery percentage}

The acceptance criteria to recover residues and contaminants from foods and water from both institutions (SSA from Mexico and the EC) were taken into consideration [30,31]. The analyte concentration $<1$ $\mu \mathrm{g} \mathrm{kg}{ }^{-1}$ had an acceptance range of $50-120 \%$ from both institutions; therefore, this range was chosen because $1 \mathrm{~g}$ of the three types of peppers was fortified with $100 \mathrm{ng}$ of each $\mathrm{AF}$ (Table 2).

\section{AF concentrations in the samples}

To detect the presence of AFs in the samples, the retention times (RTs) obtained by the experiments with the three peppers during method validation were taken into account (Table 3 ). To quantify the AFs, the recovery percentage was considered to adjust the AF quantification, as shown in Table 3. All 54 analyzed samples (19 black, 19 white and 16 green peppers) were contaminated with AFs. In total, 95\% (51/54) contained $\mathrm{AFB}_{1}, 80 \%$ (43/54) contained $\mathrm{AFB}_{2}, 67 \%(36 / 54)$ contained $\mathrm{AFG}_{1}$, and $93 \%$ contained $\mathrm{AFG}_{2}$ (50/54) (Figure 4).

The incidence of AF contamination depending on the purchaising 


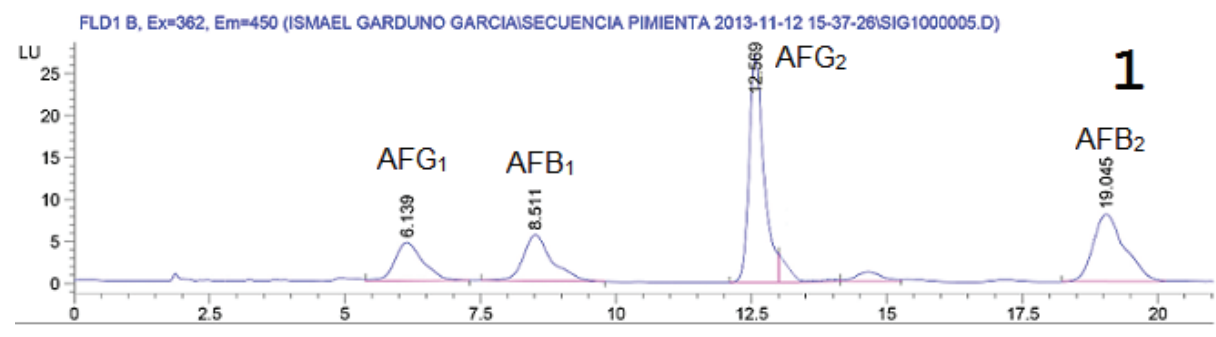

FLD1 B, EX=362, Em=450 (ISMAEL GARDUNO GARCIAISECUENCIA PIMIENTA 2013-11-12 15-37-26ISIG1000002.D)

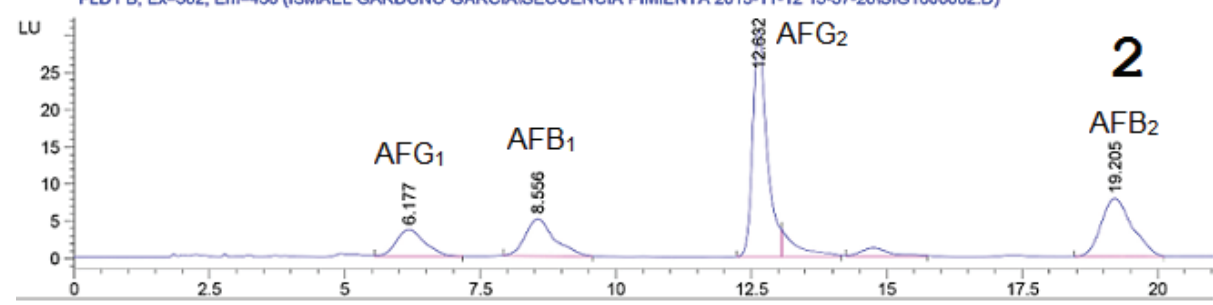

FLD1 B, EX=362, Em=450 (ISMAEL GARDUNO GARCIAISECUENCIA PIMIENTA 2013-11-11 14-16-111SIG 1000007.D)
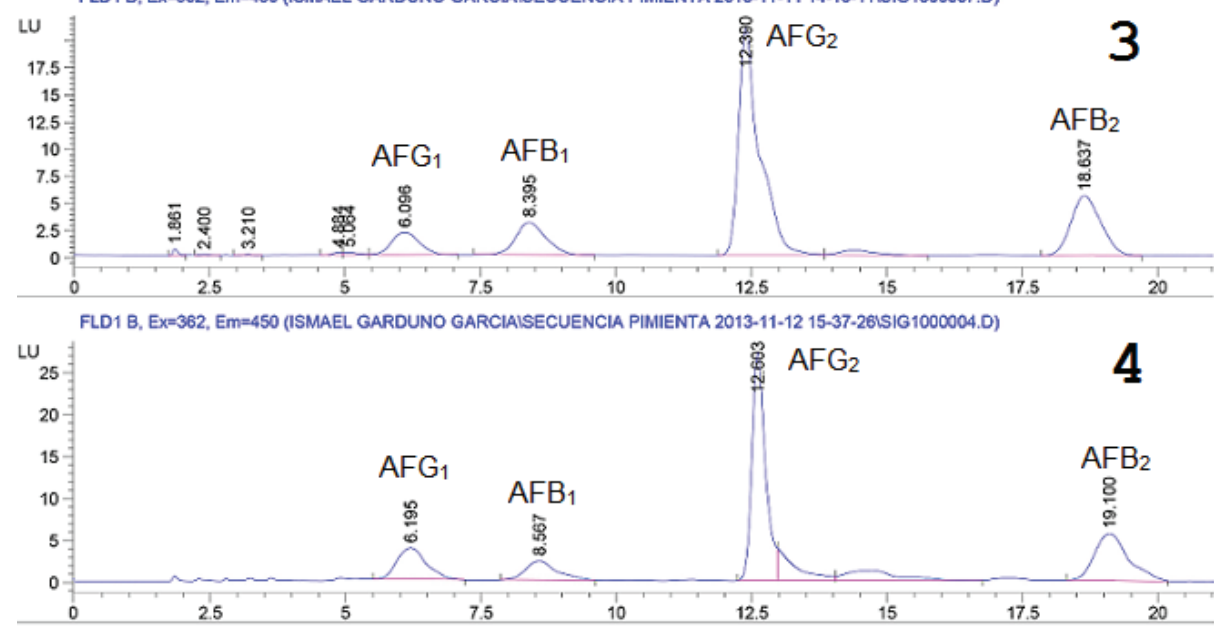

Figure 3: Chromatograms of the selectivity validation experiment. 1) Blank; 2) Black pepper; 3) White pepper; 4) Green pepper.

\begin{tabular}{|c|c|c|c|c|c|}
\hline \multirow{2}{*}{ Aflatoxin } & \multicolumn{5}{|c|}{ Validation parameters } \\
\cline { 2 - 6 } & $\begin{array}{c}\text { LOD }(\mathbf{n g} \\
\mathbf{m L}^{-1} \mathbf{)}\end{array}$ & $\begin{array}{c}\text { LOQ(ng } \\
\mathbf{m L}^{-1} \mathbf{)}\end{array}$ & $\mathbf{R}^{2}$ & $\begin{array}{c}\text { Retention times } \\
(\mathbf{m i n})\end{array}$ & $\begin{array}{c}\text { Recovery } \\
\text { percentages }\end{array}$ \\
\hline $\mathrm{AFB}_{1}$ & 0.1 & 0.5 & 0.9973 & $7.709-9.478$ & $83 \%$ \\
\hline $\mathrm{AFB}_{2}$ & 0.01 & 0.05 & 0.9908 & $17.136-19.205$ & $100 \%$ \\
\hline $\mathrm{AFG}_{1}$ & 0.01 & 0.05 & 0.9969 & $4.721-6.195$ & $80 \%$ \\
\hline $\mathrm{AFG}_{2}$ & 0.5 & 2.5 & 0.9988 & $11.319-12.995$ & $85 \%$ \\
\hline
\end{tabular}

Table 1: Validation parameters for each Aflatoxin obtained in the experiments of linearity, selectivity and recovery percentage.

place is presented in Figure 4 that show the increased susceptibility of AF contamination of the green pepper, which may be due to the degree of ripening; it is also less commercial and is stored for a longer period of time, thus increasing the risk of mycotoxigenic fungal growth. The pepper with the least contamination was the white pepper, which may be due to the polish treatment to the hull. Only $9.26 \%$ of samples (5/54) complied with the established limit of AFt given by NOM-188SSA1-2002 [37] (i.e., $20 \mu \mathrm{g} \mathrm{kg}^{-1}$ ). The samples from Mexico City that were under the legal limit were black peppers from the boroughs of Azcapotzalco and Iztacalco (16.75 and $2.56 \mu \mathrm{g} \mathrm{kg}{ }^{-1}$, respectively) and white peppers from Coyoacán, Tláhuac and Xochimilco (15.52, 7.23

\begin{tabular}{|c|c|c|c|}
\hline Pepper & Aflatoxin & Retention time (min) & Recovery \% \\
\hline Black & $\mathrm{B}_{1}$ & $(8.028-8.373)$ & 87 \\
\cline { 2 - 4 } & $\mathrm{B}_{2}$ & $(17.136-17.533)$ & 100 \\
\cline { 2 - 4 } & $\mathrm{G}_{1}$ & $(4.722-4.964)$ & 72 \\
\cline { 2 - 4 } & $\mathrm{G}_{2}$ & $(12.722-12.995)$ & 96 \\
\hline \multirow{4}{*}{ White } & $\mathrm{B}_{1}$ & $(7.931-8.235)$ & 81 \\
\cline { 2 - 4 } & $\mathrm{B}_{2}$ & $(17.176-17.465)$ & 100 \\
\cline { 2 - 4 } & $\mathrm{G}_{1}$ & $(4.904-4.724)$ & 82 \\
\cline { 2 - 4 } & $\mathrm{G}_{2}$ & $(12.675-12.861)$ & 75 \\
\hline \multirow{4}{*}{ Green } & $\mathrm{B}_{1}$ & $(7.904-8.090)$ & 82 \\
\cline { 2 - 4 } & $\mathrm{B}_{2}$ & $(18.052-18.089)$ & 89 \\
\cline { 2 - 4 } & $\mathrm{G}_{1}$ & $(4.721-4.863)$ & 83 \\
\cline { 2 - 4 } & $\mathrm{G}_{2}$ & $(12.551-12.742)$ & 82 \\
\hline
\end{tabular}

n/d: no data; RT=Retention Time

Table 2: Recovery percentage of Aflatoxins by pepper type.

and $13.4 \mu \mathrm{g} \mathrm{kg}$, respectively). The AFt concentrations in pepper according to sampling location are shown in Table 3.

All foreign samples surpassed the AFt limit of the corresponding regulations of the respective country (India $30 \mu \mathrm{g} \mathrm{kg}^{-1}$, Egypt and Turkey, $10 \mu \mathrm{g} \mathrm{kg}^{-1}$ ) (Table 4) [38]. Only Egypt and Turkey established 
Citation: Garduño-García Jl, Carvajal-Moreno M, Rojo-Callejas F, Ruiz-Velasco S (2017) Detection of Aflatoxins, Mutagens and Carcinogens in Black, White and Green Peppers (Piper Nigrum L.). J Microb Biochem Technol 9:095-104. doi: 10.4172/1948-5948.1000350

\begin{tabular}{|c|c|c|c|c|c|c|}
\hline Mexico City boroughs & Pepper sample & $\mathrm{AFB}_{1}$ & $\mathrm{AFB}_{2}$ & $\mathrm{AFG}_{1}$ & $\mathrm{AFG}_{2}$ & AFt \\
\hline \multirow[t]{3}{*}{ Álvaro Obregón } & Black & 107.47 & 17.01 & 13.61 & 19.15 & 157.24 \\
\hline & White & 21.45 & 0.39 & 2.46 & 30.33 & 54.63 \\
\hline & Green & 30.15 & $<\mathrm{LOD}$ & 10.33 & $<$ LOD & 40.48 \\
\hline \multirow[t]{3}{*}{ Azcapotzalco } & Black & 6.72 & 8.67 & $<L O D$ & 1.37 & 16.75 \\
\hline & White & 8.64 & 17.90 & $\angle L O D$ & $<\mathrm{LOD}$ & 26.54 \\
\hline & Green & 6.66 & 65.01 & 20.81 & 30.79 & 123.27 \\
\hline \multirow[t]{3}{*}{ Benito Juárez } & Black & 3.12 & 4.74 & 253.48 & 1.66 & 262.99 \\
\hline & White & $<$ LOD & 9.56 & $<$ LOD & 93.16 & 102.72 \\
\hline & Green & 33.95 & 32.33 & $<L O D$ & 18.77 & 85.04 \\
\hline \multirow[t]{3}{*}{ Coyoacán } & Black & 1.96 & 4.22 & $<\angle O D$ & 25.90 & 32.08 \\
\hline & White & 16.52 & $<\mathrm{LOD}$ & $<\angle O D$ & $<\angle O D$ & 16.52 \\
\hline & Green & 2.18 & 94.54 & $<L O D$ & 6.95 & 103.67 \\
\hline \multirow[t]{3}{*}{ Cuajimalpa } & Black & 31.29 & 13.59 & $<L O D$ & 15.55 & 60.43 \\
\hline & White & 24.14 & 16.72 & 4.54 & 35.25 & 80.65 \\
\hline & Green & 11.97 & 27.64 & $\angle L O D$ & 63.74 & 103.36 \\
\hline \multirow[t]{3}{*}{ Cuauhtémoc } & Black & 217.50 & 101.75 & $\angle L O D$ & 124.59 & 443.84 \\
\hline & White & 7.77 & 8.54 & 0.40 & 6.99 & 23.70 \\
\hline & Green & 169.59 & 175.57 & 101.48 & 151.31 & 597.95 \\
\hline \multirow[t]{3}{*}{ Gustavo A. Madero } & Black & 107.80 & 57.73 & 8.48 & 193.46 & 367.47 \\
\hline & White & 17.06 & $\angle L O D$ & 2.28 & 38.34 & 57.68 \\
\hline & Green & 16.42 & 83.20 & 17.96 & 23.45 & 141.03 \\
\hline \multirow[t]{3}{*}{ Iztacalco } & Black & $<\mathrm{LOD}$ & $<\mathrm{LOD}$ & $\angle L O D$ & 2.56 & 2.56 \\
\hline & White & 24.04 & $<$ LOD & $<L O D$ & 36.31 & 60.35 \\
\hline & Green & 136.15 & 9.86 & 611.88 & 33.23 & 791.13 \\
\hline \multirow[t]{3}{*}{ Iztapalapa } & Black & 20.22 & $<\mathrm{LOD}$ & 12.19 & 112.53 & 144.94 \\
\hline & White & 48.78 & 83.02 & 18.19 & 51.07 & 201.05 \\
\hline & Green & 18.79 & 10.04 & 10.64 & 8.89 & 48.36 \\
\hline \multirow[t]{3}{*}{ La Magdalena Contreras } & Black & 13.73 & 21.50 & $\angle L O D$ & 19.27 & 54.51 \\
\hline & White & 13.10 & 103.93 & 25.00 & 79.87 & 221.91 \\
\hline & Green & 11.05 & 60.22 & 144.57 & 494.44 & 710.29 \\
\hline \multirow[t]{3}{*}{ Miguel Hidalgo } & Black & $<L O D$ & $<\mathrm{LOD}$ & 97.07 & 64.31 & 161.38 \\
\hline & White & 4.19 & $<$ LOD & $<L O D$ & 21.34 & 25.53 \\
\hline & Green & 118.22 & 79.24 & 93.74 & 197.35 & 488.55 \\
\hline \multirow[t]{3}{*}{ Milpa Alta } & Black & 0.11 & 16.71 & $\angle L O D$ & 52.83 & 69.65 \\
\hline & White & 8.16 & 42.36 & 64.30 & 157.26 & 272.08 \\
\hline & Green & 59.35 & 243.05 & 92.71 & 149.23 & 544.34 \\
\hline \multirow[t]{3}{*}{ Tláhuac } & Black & 25.34 & 28.55 & 72.48 & 2.15 & 128.52 \\
\hline & White & 1.50 & 0.69 & $<L O D$ & 5.04 & 7.23 \\
\hline & Green & 40.14 & 67.48 & 52.77 & 237.17 & 397.56 \\
\hline \multirow[t]{3}{*}{ Tlalpan } & Black & 29.12 & 175.86 & 4.45 & 25.34 & 234.78 \\
\hline & White & 23.05 & 52.45 & $<\angle O D$ & 171.77 & 247.27 \\
\hline & Green & 27.53 & 20.17 & 17.40 & 44.89 & 110.00 \\
\hline \multirow[t]{3}{*}{ Venustiano Carranza } & Black & 8.33 & 75.47 & $\angle L O D$ & 166.00 & 249.81 \\
\hline & White & 31.17 & 108.13 & 20.52 & 68.47 & 228.29 \\
\hline & Green & 32.51 & 44.22 & 56.71 & 474.56 & 608.01 \\
\hline \multirow[t]{3}{*}{ Xochimilco } & Black & 40.26 & 28.52 & 42.83 & 57.11 & 168.72 \\
\hline & White & 13.40 & $\angle L O D$ & $\angle L O D$ & $\angle L O D$ & 13.40 \\
\hline & Green & 19.52 & 14.05 & 57.70 & 17.49 & 108.76 \\
\hline
\end{tabular}

$<\mathrm{LOD}=$ Less than the limit of detection

Table 3: Average of Aflatoxins $\left(\mu \mathrm{g} \mathrm{kg}^{-1}\right)$ in one gram of pepper from three markets of each borough in Mexico City.

a limit of $5 \mu \mathrm{g} \mathrm{kg}^{-1}$ for $\mathrm{AFB}_{1}$ and in both cases, the samples surpassed that limit [38].

The Mexican regulations with respect to $\mathrm{AFB}_{1}$ and $\mathrm{AFt}$ were not applied because commercial deals must not be regulated, and therefore, AF contamination in spices was not considered. Thus, the health of Mexicans is affected because there is no control on ingested carcinogens in foods [37].

The obtained AF concentrations varied, ranging from 0.11 to
$217.50 \mu \mathrm{g} \mathrm{kg}^{-1}$ for $\mathrm{AFB}_{1}, 0.39$ to $381.87 \mu \mathrm{g} \mathrm{kg}^{-1}$ for $\mathrm{AFB}_{2}, 0.4$ to $611.88 \mu \mathrm{g}$ $\mathrm{kg}^{-1}$ for $\mathrm{AFG}_{1}$, and 1.37 to $494.44 \mu \mathrm{g} \mathrm{kg}^{-1}$ for $\mathrm{AFG}_{2}$. (Table 5). The most contaminated samples are listed in Table 5.

\section{Statistical analysis}

The Kruskal-Wallis non-parametric test (Program R) was applied to identify potential differences in AF contamination of the three types of peppers (Table 6). The results are presented in Table 6. 


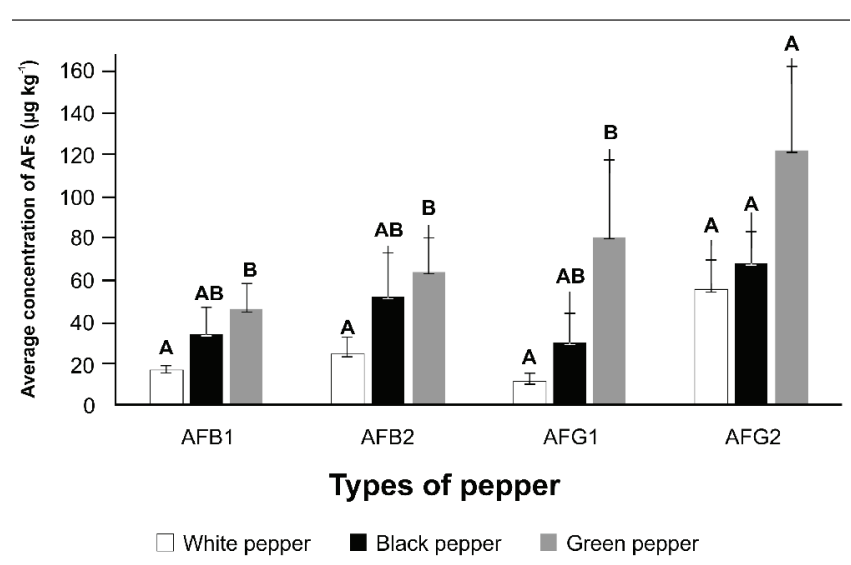

Figure 4: Average concentration of Aflatoxins in green, black, and white peppers.

Groups with one letter (A, B) in common means no significant differences according to Wilcoxon test, the concentration of $\mathrm{AFB}_{1}$ in white pepper is statistical different than the concentration in green pepper $(p=0.037)$ the concentration of $\mathrm{AFB}_{2}$ in white pepper is statistical different than the concentration in green pepper $(p=0.011)$, the concentration of $A F G_{1}$ in white pepper is statistical different than the concentration in green pepper $(p=0.011)$

\begin{tabular}{|c|c|c|c|c|c|c|}
\hline Country & Pepper sample & AFB $_{1}$ & AFB $_{2}$ & AFG $_{1}$ & AFG $_{2}$ & AFT \\
\hline \multirow{2}{*}{ Egypt } & Black & 23.92 & 381.87 & 36.51 & 104.42 & $\mathbf{5 4 6 . 7 3}$ \\
\cline { 2 - 7 } & White & 12.52 & 21.15 & 53.13 & 205.19 & 291.98 \\
\hline \multirow{3}{*}{ India } & Black & 8.40 & 27.12 & 35.30 & 118.01 & 188.83 \\
\cline { 2 - 7 } & White & 13.72 & $<$ LOD & 9.51 & 14.37 & 37.60 \\
\hline \multirow{2}{*}{ Turkey } & Black & 7.87 & 30.63 & 1.11 & 185.92 & 225.53 \\
\cline { 2 - 7 } & White & 27.10 & $<$ LOD & 18.57 & 35.15 & 80.81 \\
\hline
\end{tabular}

Table 4: Aflatoxins $\left(\mu \mathrm{g} \mathrm{kg}^{-1}\right)$ in $1 \mathrm{~g}$ of pepper in Egypt, India and Turkey.

\begin{tabular}{|c|c|c|c|}
\hline Aflatoxin & Pepper type & $\begin{array}{c}\text { Purchasing place: } \\
\text { Mexico City boroughs } \\
\text { or country }\end{array}$ & $\begin{array}{c}\text { Concentración de AF } \\
\mathbf{( \mu g ~ k g}^{-1} \mathbf{)}\end{array}$ \\
\hline \multirow{2}{*}{$\mathrm{B}_{1}$} & Black & Cuauhtémoc & 217.50 \\
\cline { 2 - 4 } & White & Iztapalapa & 48.78 \\
\cline { 2 - 4 } & Green & Cuauhtémoc & 169.59 \\
\hline \multirow{2}{*}{$\mathrm{B}_{2}$} & Black & Egypt & 381.87 \\
\cline { 2 - 4 } & White & V. Carranza & 108.13 \\
\cline { 2 - 4 } & Green & Milpa Alta & 243.05 \\
\hline \multirow{2}{*}{$\mathrm{G}_{1}$} & Black & Benito Juárez & 253.48 \\
\cline { 2 - 4 } & White & Milpa Alta & 64.30 \\
\cline { 2 - 4 } & Green & Iztacalco & 611.88 \\
\hline \multirow{2}{*}{$\mathrm{F}_{2}$} & Black & G. A. Madero & 193.46 \\
\cline { 2 - 4 } & White & Egypt & 205.19 \\
\cline { 2 - 4 } & Green & La M. Contreras & 494.44 \\
\hline \multirow{2}{*}{ AFt } & Black & Egypt & 546.73 \\
\cline { 2 - 4 } & White & Egypt & 291.98 \\
\cline { 2 - 4 } & Green & Iztacalco & 791.13 \\
\hline
\end{tabular}

Table 5: The most contaminated pepper samples according to the purchasing place.

There were no significant differences between the three types of peppers studied with respect to $\mathrm{AFB}_{1}$ and $\mathrm{AFG}_{2}$, but significant differences in $\mathrm{AFB}_{2}, \mathrm{AFG}_{1}$ and $\mathrm{AFt}$ were observed.

The Wilcoxon signed-rank test was performed to detect significant differences among the groups. There were no significant differences in green pepper, although this pepper is more susceptible to $\mathrm{AF}$

\begin{tabular}{|c|c|c|c|}
\hline Aflatoxin & Kruskal-Wallis test & Significance & Significant difference \\
\hline $\mathrm{AFB}_{1}$ & 4.41 & 0.11 & No \\
\hline $\mathrm{AFB}_{2}$ & 7.11 & $<0.05$ & Yes \\
\hline $\mathrm{AFG}_{1}$ & 7.05 & $<0.05$ & Yes \\
\hline $\mathrm{AFG}_{2}$ & 0.93 & 0.63 & No \\
\hline $\mathrm{AFt}$ & 7.49 & $<0.05$ & Yes \\
\hline
\end{tabular}

Table 6: Kruskal-Wallis test for aflatoxins in peppers.

contamination. $\mathrm{AFG}_{1}$ contamination was the highest, with an average value of $35.88 \mu \mathrm{g} \mathrm{kg}^{-1}$.

White pepper was the least contaminated, but was more susceptible to $\mathrm{AFG}_{2}$, reaching an average value of $25.13 \mu \mathrm{g} \mathrm{kg}^{-1}$. An intermediate incidence of contamination was observed in black pepper, which reached a maximum average value of $27.53 \mu \mathrm{g} \mathrm{kg}^{-1}$ for $\mathrm{AFG}_{2}$.

The lack of pepper contamination could be due to essential oils that contain substances such as piperin, which is important in pepper composition [39]. The levels of AF contamination in peppers from Mexico surpassed the tolerance limits set by other countries. Turkey had $\mathrm{AFB}_{1}$ concentrations ranging from 0.3 to $1.2 \mu \mathrm{g} \mathrm{kg}^{-1}$ and $\mathrm{AFt}$ concentrations ranging from 0.3 to $2.3 \mu \mathrm{g} \mathrm{kg}^{-1}$ in black pepper [40]. Ranges of AFt from 1.1 to $97.5 \mu \mathrm{g} \mathrm{kg}^{-1}$ in red pepper have been reported [41]. In Korea, ground red pepper samples had AFt levels ranging from 0.08 to $4.66 \mu \mathrm{g} \mathrm{kg}^{-1}$, whereas black pepper had only trace amounts below the LOD [42]. In Italy, whole pepper and ground black pepper also had only trace amounts below the LOD [43].

Pepper is a good substrate for the growth of Aspergillus spp. aflatoxicogenic fungi and thus AF metabolic production. High levels of AFs indicate improper handling at some stages of the production chain and in some supplies, including bad practices during harvest, inappropriate storage or a lack of good conditions during transportation, marketing and/or processing [10].

Essential oils from some spices inhibit fungal growth and mycotoxin production [44]. The essential oils of clover, cumin and black pepper can inhibit the fungi that produce AFs. Oils, such as eugenol, eugenol acetate, $B$ cariophylene and piperin, also inhibit AFs [39]. Matrices such as black pepper and cumin are not good substrates for AF biosynthesis due to their essential oils, although they allow fungal growth [40]. In the case of $A$. parasiticus, AF production is inhibited in black and white peppers by the actions of piperin and other volatile essential oils [39]. Some scientists did not detect AFs in black or white ground pepper, suggesting that these peppers are not an appropriate substrate for AF biosynthesis [45]. The antifungal power of the dioic pepper has been proven in vitro against molds, such as Aspergillus candidus, A. versicolor, Penicillum citrinum, $P$. aurantiogriseum, $P$. brevicompactum and $P$. griseofulvum, as well as in situ against the post-harvestcontaminating molds of oat grains, namely, Fusarium spp., Alternaria spp. and Cladosporium spp., where extracts of dioic pepper inhibit fungal growth in vitro [46].

The main pungent compound of pepper is piperin (1-[5-[1,3-bensodioxol-5-il]-1-oxo-2,4, pentadyenil] piperedin), which gives pepper its flavor and odor. Piperin is an immunomodulator, anticarcinogen, anti-asthmatic, anti-inflammatory, liver-protective and antimicrobial that prevent ulcer formation [47-49]. From a nutritional point of view, black pepper is a good source of manganese, iron, vitamins $\mathrm{A}, \mathrm{C}, \mathrm{E}$ and $\mathrm{K}$, niacin, and folate, with low fat $(0.12 \mathrm{~g})$ and protein $(0.48 \mathrm{~g})$ contents, as well as dietetic fiber. Two spoons $(4.28 \mathrm{~g})$ of black pepper have 10.88 calories [50]. 
There are several protective mechanisms in the human body against $\mathrm{AFs}$. In the case of $\mathrm{AFB}_{1}$, the liver biotransforms xenobiotics by the action of phase I and II enzymes and can cause AFs to be excreted in the bile or kidney. However, some phase I metabolites can react with different biomolecules, rendering them unstable [51].

$\mathrm{AFB}_{1}-8,9$-epoxide is the active metabolite of $\mathrm{AFB}_{1}$. With the aid of the liver microsomal enzyme CYTP450, a covalent linkage with nitrogen $7\left(\mathrm{~N}^{7}\right)$ of guanine occurs and $\mathrm{AFB}_{1}-\mathrm{N}^{7}$-guanine $\left(\mathrm{AFB}_{1}-\mathrm{N}^{7}\right.$ Gua) adducts are formed in target cells $[52,53]$. The adduct produces an apurinic site in the guanine imidazole ring that, when it opens, becomes the highly stable mutagenic adduct $\mathrm{AFB}_{1}$-formamidepyrimidin $\left(\mathrm{AFB}_{1}\right.$ FAPY). The activation and reaction of $\mathrm{AFB}_{1}$ with $\mathrm{ADN}$ has been studied [54]. This results in a guanine-thymine $(\mathrm{G} \rightarrow \mathrm{T})$ transversion in codon 249 of the p53 tumor suppressor gene and to DNA lesions, mutations and the beginning of cancer with tumor formation [55,56].

The reactive epoxide can be hydrolyzed to $\mathrm{AFB}_{1}-8-9$-dihidrodiol, which is ionized to form a Schiff base with amino primary groups in proteins [57]. The epoxide has a short life and has been associated with blood coagulation, decreased synthesis of vitamin $\mathrm{K}$ and other clot factors as a result of sub-lethal intoxication [58].

With respect to its cytotoxic effects, $\mathrm{AFB}_{1}$ induces lipid peroxidation in the rat liver, resulting in oxidative damage to hepatocytes [59].

AF contamination of spices is a serious problem worldwide that can affect international trade. Black pepper is a valuable spice that is usually contaminated microbiologically, as well as by mycotoxins during harvest and processing; black pepper has large drying periods and requires sunlight $[60,61]$. Pepper grows in tropical, humid countries that promote the growth of fungi and the production of mycotoxins [62]. Spices, including pepper, are frequently added to foods, although they contribute to many health problems because they are highly contaminated with AFs.

Spices with AFs over the tolerated limit have been reported in the United Kingdom [63]. In fact, $43 \%$ of packed spices in Portuguese markets are reportedly contaminated with $\mathrm{AFB}_{1}$ [62]. In Qatar, a mixture of spices and chili peppers had AFs ranging from 0.16 to 69.28 $\mu \mathrm{kg}^{-1}[64]$.

AF analysis in spices is not simple due to the interference of colored materials that are extracted with AFs. Selective extraction and specific purification of AFs before quantification is recommended. Immunoaffinity columns with specific antibodies against AFs are efficient for their purification and concentration [42]. The analytical methods used for AF identification and quantification include thin layer chromatography (TLC) and liquid (HPLC) chromatography with fluorescence detectors as well as immunosorbent assays that involve enzyme bonding (ELISA) $[65,66]$.

Due to the high toxicity of AFs, their reduction in foods is a worldwide goal. Adequate humidity, weed control and crop rotation can help to reduce the amount of AFs in foods. Extra irrigation, fast mechanical drying and an early harvest can also reduce AF contamination levels [67].

There are several biological detoxification methods that could be applied to reduce non-toxic strains of Aspergillus flavus and other molds [68]. The physical methods include extraction, heating and absorption with adsorbent agents, and radiation [69]. The chemical methods include treatment with ammonia, sodium bisulfite, calcium hydroxide, formaldehyde, antioxidants or other chemicals [70].
Insect infestation in agricultural products promotes fungal inoculation and subsequent $\mathrm{AF}$ contamination. Insect damage to the fruit surface creates infectious routes for the dispersion of fungal pathogens; therefore, pest control is important for AF control [71]. The Bt toxin produced by Bacillus thuringiensis is an efficient control that has been used in France since 1938. It is safe to use in foods for humans or in feed. However, more than $220 \mathrm{Bt}$ toxin strains against different insects have been identified [72].

Our study suggests that pepper is the most AF-contaminated matrix; the AF amounts contained in pepper surpass the AF contamination of peanuts. Based on our experience, we conclude that the amounts of AFs in pepper are among the highest found in foods. Although the $\mathrm{AF}$ concentrations in pepper are high, their ingestion in different dishes is minimal because they are used in small quantities as a flavorenhancing product. Therefore, the contribution of AFs from peppers to an organism can be considered to be relatively low in comparison to other agricultural products, such as maize, pistachio, peanuts or dairy products.

This study presents a detailed analysis of AF contamination in pepper in three different ripening stages (green, black and white). The lack of normativity in countries on this subject prevents the reduction of AF concentrations in the diet.

\section{Conclusion}

The extraction and purification methods of AFs in pepper were validated. The recovery values were $>80 \%$, indicating good recovery of the four AFs. Four types of AFs were identified and quantified in the three types of pepper. All the analyzed samples were contaminated with at least one AF. The high AF content in pepper could be due to inadequate handling and storage conditions. Only $9.26 \%$ of the samples from Mexico City complied with the $20 \mu \mathrm{g} \mathrm{kg}^{-1}$ limit established by the NOM-188-SSA1-2002 for AFt. All foreign samples surpassed the AFt limits established by their respective countries (India $30 \mu \mathrm{g} \mathrm{kg}{ }^{-1}$, Egypt and Turkey, $10 \mu \mathrm{g} \mathrm{kg}^{-1}$ ). Samples from Egypt and Turkey also surpassed the $\mathrm{AFB}_{1}$ limit $\left(5 \mu \mathrm{g} \mathrm{kg}^{-1}\right)$.

The levels of $\mathrm{AFB}_{2}, \mathrm{AFG}_{1}$ and $\mathrm{AFt}$ contamination were significantly different among the three types of pepper. The amount of $\mathrm{AFB}_{1}$ and $\mathrm{AFG}_{2}$ did not differ significantly. Green pepper was the most contaminated with $\mathrm{AFs}$, white pepper was the least contaminated and black pepper had an intermediate level of contamination. Drying by sunlight is not efficient for AF degradation. Based on our results, ripening plays a major role in $\mathrm{AF}$ levels because green pepper was the most highly contaminated and the least ripened.

\section{Acknowledgement}

The authors thank Instituto de Biología, Universidad Nacional Autónoma de México (IBUNAM) for the analysis of this work. Thanks also to IBUNAM's personnel: Noemí Chávez from the Secretaría Técnica, Joel Villavicencio, Jorge López, Alfredo Wong, Diana Martínez and Julio César Montero provided valuable assistance with imaging, computer analysis and design. Additionally, we thank Georgina Ortega Leite and Gerardo Arévalo for library information.

\section{References}

1. Nelson SC, Eger KT (2011) Farm and forestry production and marketing profile for black pepper (Pipper nigrum). In: Elevitch CR (ed). Specialty crops for Pacific Island agroforesty. Permanent Agriculture Resources (PAR), Holualoa, Hawaii.

2. Financiera Rural (2011) Dirección General Adjunta de Planeación Estratégica y Análisis Sectorial, Dirección Ejecutiva de Análisis Sectorial. Monografía de la Pimienta.

3. Field Financial (2011) General associate direction of strategy planification 
Citation: Garduño-García JI, Carvajal-Moreno M, Rojo-Callejas F, Ruiz-Velasco S (2017) Detection of Aflatoxins, Mutagens and Carcinogens in Black, White and Green Peppers (Piper Nigrum L.). J Microb Biochem Technol 9:095-104. doi: 10.4172/1948-5948.1000350

and sectorial analysis, executive direction of sectorial analysis. Pepper Monography. Accessed on October 28, 2013.

4. IPC, International Pepper Community (2010) Pepper Statistics 2001-2010

5. Brand-Miller JC, Barclay AW (2017) Declining consumption of added sugars and sugar-sweetened beverages in Australia: A challenge for obesity prevention. Am J Clin Nutr 105: 854-863.

6. Ned Spice (2013) Pepper Crop Report 2013. Accessed on May 2013.

7. Chu FS (1997) Mode of action of mycotoxins and related compounds. Adv Appl Microbiol 22: 83-143.

8. Midio AF, Campos RR, Sabino M (2001) Occurrence of aflatoxins B1, B2, G1 and G2 in cooked food components of whole meals marketed in fast food outlets of the city of São Paulo, SP, Brazil. Food Addit Contam 18: 445-448.

9. Soriano JM (2007) Micotoxinas en alimentos. Ediciones Díaz de Santos. España. [Soriano JM (2007) Food Mycotoxins. Ediciones Díaz de Santos. Spain].

10. Erkmen O, Bozoglu TF (2008) Food Microbiology 1: Microorganisms in foods, microbial growth, foodborne diseases and detection of microorganisms and their toxins. Ilke Publishing Company, Ankara, Turkey.

11. Wagacha JM, Muthomi JW (2008) Mycotoxin problem in Africa: Current status, implications to food safety and health and possible management strategies. Int J Food Microbiol 124: 1-12.

12. Hussein HS, Brasel JM (2001) Toxicity, metabolism and impact of mycotoxins on humans and animals. Toxicology 167: 101-134.

13. Bhat RV, Krishnamachari KAVR (1977) Follow-up study of aflatoxic hepatitis in parts of Western India. Indian J Med Res 66: 55-58.

14. Groopman JD, Zhu JQ, Donahue PR, Pikul A, Zhang LS, et al. (1992) Molecular dosimetry of urinary aflatoxin-DNA adducts in people living in Guangxi autonomous region, People's Republic of China. Cancer Res 52: 45-52.

15. Becroft DM, Webster DR (1972) Aflatoxins and Reye's disease. Br Med J 4: 117.

16. Campbell TC, Stoloff L (1974) Implication of mycotoxins for human health. J Agric Food Chem 22: 1006-1015.

17. IARC, International Agency for the Research of Cancer (2002) Some traditional herbal medicines, some mycotoxins, naphthalene and styrene. IARC Monographs on the evaluation of carcinogenic risks to humans. IARC Sci Publ, Lyon, France 82: 171.

18. Codex Alimentarius (2008) Codex General Standard for contaminants and toxins in food and feed. JECFA. Codex Stan193-1995: 9.

19. Jacobs JP, Wernovsky G, Elliott MJ (2007) Analysis of outcomes for congenita cardiac disease: Can we do better? Cardiol Young 17 Suppl 2: 145-158.

20. Muench KF, Misra RP, Humayun MZ (1983) Sequence specificity in aflatoxin B1-DNA interactions. Proc Natl Acad Sci 80: 6-10.

21. Paul PS, Johnson DW, Mirocha CJ, Soper FF, Thoen CC, et al. (1977) In vitro stimulation of bovine peripheral blood lymphocytes: suppression of phytomitogen and specific antigen lymphocyte responses by aflatoxin. Am J Vet Res 38: 2033-2035.

22. Fernández A, Hernández M, Verde MT, Sanz M (2000) Effect of aflatoxin on performance, hematology and clinical immunology in lambs. Can J Vet Res 64: 53-58.

23. Pang VF, Pan CY (1994) The cytotoxic effects of aflatoxin B1 on swine lymphocytes in vitro. J Chinese Soc Vet Sci 20: 289-301.

24. Helferich WG, Garrett WN, Hsieh DPH, Baldwin RL (1986) Feed lot performance and tissue residues of cattle consuming diets containing aflatoxins. J Anim Feed Sci 62: 691-696.

25. Kiessling KH, Pettersson H, Sandholm K, Olsen M (1984) Metabolism of aflatoxin, ochratoxin, zearalenone and three tricothecenes by intact rumen fluid, rumen protozoa and rumen bacteria. Appl Environ Microbiol 47: 10701073.

26. Perusia OR, Rodríguez R (2001) Micotoxicosis. Rev Investig Vet Peru 12: 87 116.

27. Wogan GN (1966) Chemical nature and biological effects of the aflatoxins. Bacteriol Rev 30: 460-470.
28. Butler WH, Neal GE (1977) Mode of action and human health aspects of aflatoxin carcinogenesis. Pure Appl Chem 49: 1747-1751.

29. Willis RM, Mulvihill JJ, Hoofnagle JH (1980) Attempted suicide with purified aflatoxin. Lancet 315: 1198-1199.

30. WPR, World Population Review (2017) Mexico Population on February 8, 2017.

31. COESPO, Consejo Estatal de Población (2012) Población total del Estado de México por municipio. Secretaría General de Gobierno.

32. SSA, Secretaría de Salud (2011) Comisión de control analítico y ampliación de cobertura, Criterios para la validación de métodos fisicoquímicos.

33. Comisión Europea (2006) Reglamento $N^{\circ} 401 / 2006$ por el que se establecen los métodos de muestreo y de análisis para el control oficial del contenido de micotoxinas en los productos alimenticios.

34. European Commission (2006) Rule $N^{\circ} 401 / 2006$ that establishes the sampling and analytical methods for the official control of mycotoxins in food products.

35. AOAC, Association of Official Analytical Chemist International (2006) Official methods of analysis of AOAC International. Natural Toxins. In: Trucksess MW. Chapter Ed. Chapter 49:1-99.

36. MSCR, Ministerio de Salud de Costa Rica (2002) Guía de validación de métodos analíticos.

37. MSCR, Health Ministry of Costa Rica (2002) Validation guide for analytical methods.

38. R-Biopharm Rhone Ltd (2012) Easi-extract aflatoxin. Guía de uso para e usuario. RP71RP70N/V12/28.06.12. Block 10 Todd Campus, West of Scotland Science Park. Acre Road, Glasgow G20 0XA. UK.

39. Kok WT (1994) Derivatization reactions for the determination of aflatoxins by liquid chromatography with fluorescence detection. J Chromatogr B 659: 127-137.

40. Akiyama H, Goda Y, Tanaka T, Toyoda M (2001) Determination of aflatoxins $\mathrm{B} 1, \mathrm{~B} 2, \mathrm{G} 1$ and $\mathrm{G} 2$ in spices using a multifunctional column clean-up. J Chromatogr A 932: 153-157.

41. Norma Oficial Mexicana. NOM-188-SSA1-2002, Productos y Servicios (2002) Control de Aflatoxinas en cereales para consumo humano y animal. Especificaciones sanitarias.

42. Mexican Official Norm NOM-188-SSA1-2002, Products and Services (2002) Aflatoxin control in cereals for human and animal consumption. Sanitary Specifications.

43. Turkish Food Codex Regulation on Contaminants (2011) Official Gazette, No. 28157.

44. Madhyastha SM, Bhat VR (1984) Aspergillus parasiticus growth and aflatoxin production on black and white pepper and the inhibitory action of their chemical constituents. Appl Environ Microbiol 48: 376-379.

45. Bircan C (2005) The determination of aflatoxins in spices by immunoaffinity column extraction using HPLC. Int J Food Sci Tech 40: 929-934.

46. Erdogan A (2004) The aflatoxin contamination of some pepper types sold in Turkey. Chemosphere 56: 321-325.

47. Cho SH, Lee CH, Jang MR, Son YW, Lee SM, et al. (2008) Aflatoxins contamination in spices and processed spice products commercialized in Korea. Food Chem 107: 1283-1288.

48. Romagnoli B, Menna V, Gruppioni N, Bergamini C (2007) Aflatoxins in spices, aromatic herbs, herb-teas and medicinal plants marketed in Italy. Food Control 18: 697-701.

49. Karapinar M (1985) The effects of citrus oils and some spices on growth and aflatoxin production by Aspergillus parasiticus NRRL 2999. Int J Food Microbio 2: $239-245$.

50. Scott PM, Kennedy BPC (1973) Analysis and survey of ground black, white and capsicum peppers for aflatoxins. J AOAC 56: 1452-1457.

51. Scholz K, Vogt M, Kunz B, Lyr H, Russell PE, et al. (1999) Application of plant extracts for controlling fungal infestation of grains and seeds during storage. Modern fungicides and anti-fungical compounds II. 12th International Reinhardshbrunn Symposium, Friedrichroda, Thuringia, Germany.

52. Darshan S, Doreswamy R (2004) Patented anti-inflammatory plant drug development from traditional medicine. Phytother Res 18: 343-357. 
Citation: Garduño-García Jl, Carvajal-Moreno M, Rojo-Callejas F, Ruiz-Velasco S (2017) Detection of Aflatoxins, Mutagens and Carcinogens in Black, White and Green Peppers (Piper Nigrum L.). J Microb Biochem Technol 9:095-104. doi: 10.4172/1948-5948.1000350

53. Yang YC, Lee SG, Lee HK (2002) A piperidine amide extracted from $P$. longum L. fruit shows activity against Aede aegypti mosquito larvae. J Agric Food Chem 50: 3765-3767.

54. Bai YF, Xu H (2000) Protective action of piperine against experimental gastric ulcer. Acta Pharm Sinic 21: 357-359.

55. Waard PWF, Anunciado IS (1999) Pipernigrum L. [Internet] Record Proseabase. De Guzman CC, Siemonsma JS (eds). PROSEA (Plant Resources of SouthEast Asia) Foundation, Bogor, Indonesia.

56. Uribe-Yunda DF, Navas MC (2012) Mecanismos moleculares involucrados en la mutagenicidad inducida por aflatoxina B1. Rev Cienc Salud 10: 403-419.

57. Lillehoj EB (1991) Aflatoxin: an ecologically elicited genetic activation signal. In: Smith JE, Henderson RA (Eds) Mycotoxins and Animal Foods. 1-35. CRC Press, Boca Raton FL USA.

58. Bailey GS (1994) Role of aflatoxin-DNA adducts in the cancer process. In: Eaton DL, Groopman JD (Eds.). The Toxicology of Aflatoxins: Human Health, Veterinary, and Agricultural Significance. Academic Press, San Diego, CA USA

59. Smela ME, Hamm ML, Henderson PT, Harris CM, Harris TM, et al. (2002) The aflatoxin B1 formamidopyrimidine adduct plays a major role in causing the types of mutations observed in human hepatocellular carcinoma. Proc Nat Acad Sci USA 99: 6655-6660.

60. Wang JS, Groopman JD (1999) DNA damage by mycotoxins. Mutat Res 424: 167-181.

61. Foster PL, Einsenstadt E, Miller JH (1983) Base substitution mutations induced by metabolically activated aflatoxin B1. P Natl Acad Sci USA 80: 2695-2698.

62. Raney KD, Meyer DJ, Ketterer B, Harris TM, Guengerich FP (1992) Glutathione conjugation of aflatoxin B1 exo- and endo-epoxides by rat and human glutathione-S-transferases. Chem Res Toxicol 5: 470-478.

63. Bababunmi EA, Thabrew I, Bassir O (1997) Aflatoxin induced coagulopathy in different nutritionally classified animal species. World Rev Nutr Diet 34: 161-181.

64. Shen HM, Ong CN, Shi CY (1995) Involvement of reactive oxygen species in aflatoxin B1-induced cell injury in cultured rat hepatocytes. Toxicology 99: 115-123.
65. Jalili M, Jinap S (2012) Reduction of mycotoxins in white pepper. Food Addit Contam Part A Chem Anal Control Expo Risk Assess 29: 1947-1958.

66. Banerjee M, Sarkar PK (2003) Microbiological quality of some retail spices in India. Food Res Int 36: 469-474.

67. Martins ML, Martins HM, Bernardo F (2001) Aflatoxins in spices marketed in Portugal. Food Addit Contam 18: 315-319.

68. MacDonald S, Castle L (1996) A UK retail survey of aflatoxins in herbs and spices and their fate during cooking. Food Addit Contam 13: 121-128.

69. Abdulkadar WHA, Al-Ali AA, Al-Kildi MA, Al-Jedah HJ (2004) Mycotoxin in food products available in Qatar. Food Control 15: 543-548.

70. Bacaloni A, Cavaliere C, Cucci F, Foglia P, Samperi R et al. (2008) Determination of aflatoxins in hazelnuts by various simple preparation methods and liquid chromatography-tandem mass spectrometry. J Chromatogr 1179:182-189.

71. Hu YY, Zheng P, Zhang ZX, He YZ (2006) Determination of aflatoxins in high-pigment contents samples by matrix solid-phase dispersion and highperformance liquid chromatography. J Agric Food Chem 54: 4126-4130.

72. Pitt Jl (2013) Mycotoxins. Food-borne infections and intoxications. Elsevier Acad Press. Amsterdam, The Netherlands.

73. Dorner JW, Cole RJ, Connik WJ, Daigle DJ, Mc Guire MR et al. (2003) Evaluation of biological control formulations to reduce aflatoxin contamination in peanuts. Biol Control 26: 318-324.

74. Herzallah S, Alshawabkeh K, AL Fataftah A (2008) Aflatoxin decontamination of artificially contaminated feeds by sunlight, gamma radiation and microwave heating. J Appl Poultry Res 17: 515-521.

75. Doyle MP, Marth EH (1978) Bisulfite degrades aflatoxin: Effect of citric acid and methanol and possible mechanism of degradation. J Food Prot 41: 891-896.

76. Abbas HK, Zablotowicz RM, Weaver MA, Shier WT, Bruns HA, et al. (2013) Implications of Bt traits on mycotoxin contamination in maize: Overview and recent experimental results in Southern United States. J Agric Food Chem 61: 11759-11770.

77. Martin P, Travers R (1989) Worldwide abundance and distribution of Bacillus thuringiensis isolates. Appl Environ Microbiol 55: 2437-2442. 